\title{
THE STRUCTURE, TADPOLE AND BUDDING OF THE ASCIDIAN PYCNOCLAVELLA AURILUCENS GARSTANG
}

\author{
By N. J. Berrill \\ From the Plymouth Laboratory and McGill University, Montreal
}

(Text-figs. I-3)

Pycnoclavella aurilucens was recorded and briefly described by Garstang in I89I from a limited locality in the Plymouth area, and has not been found with certainty of identification from any other region. There has been a tendency to subordinate it as a species of Clavelina, but the dissimilarities are greater even than the original description implies and this procedure is not justified. The genus is accordingly retained, and a more detailed account of the colony, with the first description of the tadpole larva and process of budding, is presented.

Colonies are usually found growing on gorgonians, large hydroids and calcareous algae at depths of $25-30 \mathrm{~m}$. associated with coarse shell gravel and polyzoa such as Lepralia. It is known to occur only in the Plymouth region, unless the form known as Clavelina nana reported from Roscoff and Banyuls (Giard, 1873, Lahille, 1890) turns out to be identical with it. The external appearance of the colonies and of the constituent zooids has been well described by Garstang in the second volume of this fournal. In brief, the colonies are encrusting, the thoracic parts of the small delicate zooids extending freely from a greenish matrix in which the abdomens are embedded. The endostyle and peripharyngeal bands are picked out in yellow or white pigment and are very striking; the zooids are very contractile.

\section{STRUCTURE OF THE ZOOID}

The zooids (Fig. I) in general structure are much like those of Clavelina. They are much smaller and consequently have a less elaborate branchial sac, there being seven rows of gill-slits, rarely eight or nine. The endostyle is comparatively massive, as noted by Garstang, and the siphons independent and without lobes as is in other members of the Clavelinidae. Dorsal languets, corresponding in number to the rows of stigmata, occur along the dorsal line of the branchial sac. The oesophagus is long, the stomach squarish in crosssection as in Clavelina and leading into a typical post-stomach, the latter in turn connected with the intestine proper by a vertically aligned mid-intestine. The rectum opens into the atrial cavity level with the most posterior row of 


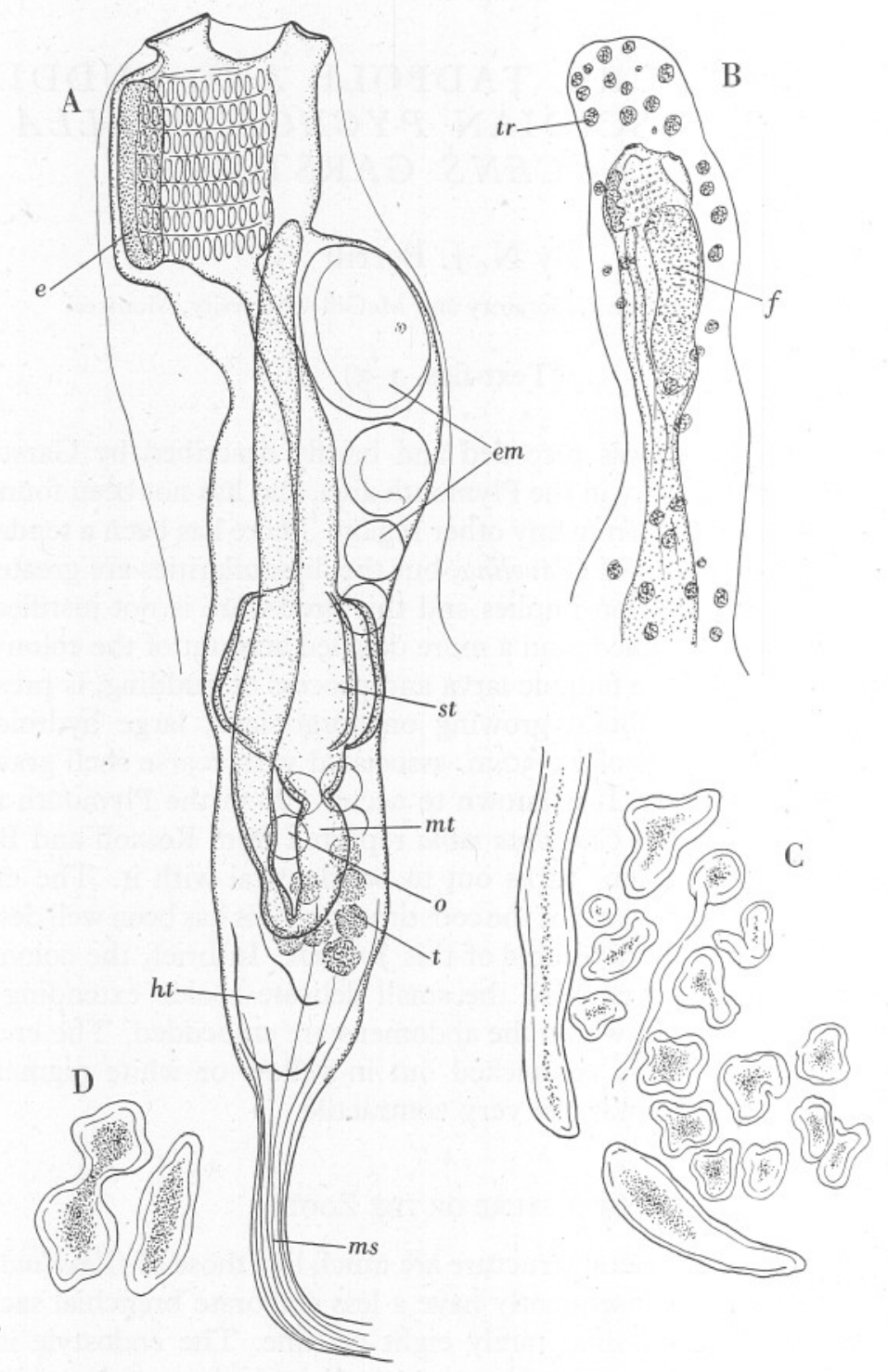

Fig. I. A, mature zooid of Pycnoclavella, with ventral stolon incomplete and embi veloping within oviduct. $\mathrm{B}$, zooid undergoing resorption after end of sexual $\mathrm{b}$ phase, with large 'trophocytes' accumulating in test. C, distal end of ventra showing separation of ampullary bud chambers and fragmentation of stolo $\mathrm{D}$, isolated buds from another part of colony. e, endostyle; em, embryos; trapped in resorbing intestine; $h t$, heart; $m s$, muscle fibres in ventral stolon; intestine; $o$, ovary; st, stomach; $t$, testis; $t r$, trophocyte. 
gill-slits. The heart lies posterior to the loop of the digestive canal, and is virtually straight. The epicardium extends throughout the length of the abdomen in a fused condition, its double nature indicated only by a shallow bilobed condition at its posterior extremity level with the bend of the gutloop, and anteriorly as a pair of horns ending blindly just beneath the branchial sac from which it arises during development.

As in Clavelina there is a prolonged post-abdominal extension of the body wall in which the longitudinal retractor muscles are included. Other structures or organs do not extend into this stalk or stolon, so that it is not a postabdomen of the kind encountered in the Synoicidae. Posteriorly the stolon tends to branch and processes may be reflected along the sides of the abdomen.

The gonads lie posterior to the stomach alongside the posterior part of the gut-loop. Both the sperm duct and oviduct open at the base of the atrial cavity. The oviduct is wide and eggs are fertilized while within it, early cleavage stages occurring near the level of the stomach and later stages up to the mature tadpole larva being found more anteriorly.

\section{BUDDING}

The process of budding is apparently essentially similar to that of species of Clavelina. The posterior end of the post-abdominal stolonic extension branches and breaks up into ampullary chambers, somewhat larger fragments arising from fragmentation of the main stalk. These pieces consist of a layer of epidermis of irregular form, and contain mesenchymatous tissue that served originally as part of the mesenchymatous septum separating the afferent and efferent blood flow in the stolon. Actual separation of a united ampullary cluster into isolated fragments appears to be mainly a phenomenon of early or mid-winter, and development into new zooids never takes place while tissue continuity is retained with the parent zooid.

Nutrition of a bud appears to be somewhat different from that of Clavelina proper, though it is none too well known and neither is the development of the bud itself. There is clearly some concentration of reserve food cells within the bud fragments, but not to a comparable degree, and it is possible that the medium of the common matrix external to the buds may become nutritional as in Distaplia. In any event, as the zooids of a colony begin to resorb after the close of the sexual breeding phase, cells lying within or migrating into the thoracic and abdominal tunic become greatly enlarged and closely resemble the trophocytes of other forms, and such cells together with other dissolution products undoubtedly comprise the entire source of nutrition for the buds in Distaplia colonies. The process of resorption follows an orderly course and the reduction of structures and tissues is in general like that described for Clavelina by Huxley (I926). 


\section{Development and StRUCtURE of TAdPole}

The egg is comparatively yolky and as such is relatively small, of about $0.28 \mathrm{~mm}$. diameter (Fig. 2A). Fertilization occurs at the base of the oviduct by sperm entering from the atrial chamber. The pattern of early cleavage is not known, though in the equally yolky eggs of Amaroucium (Scott, I945) the basic

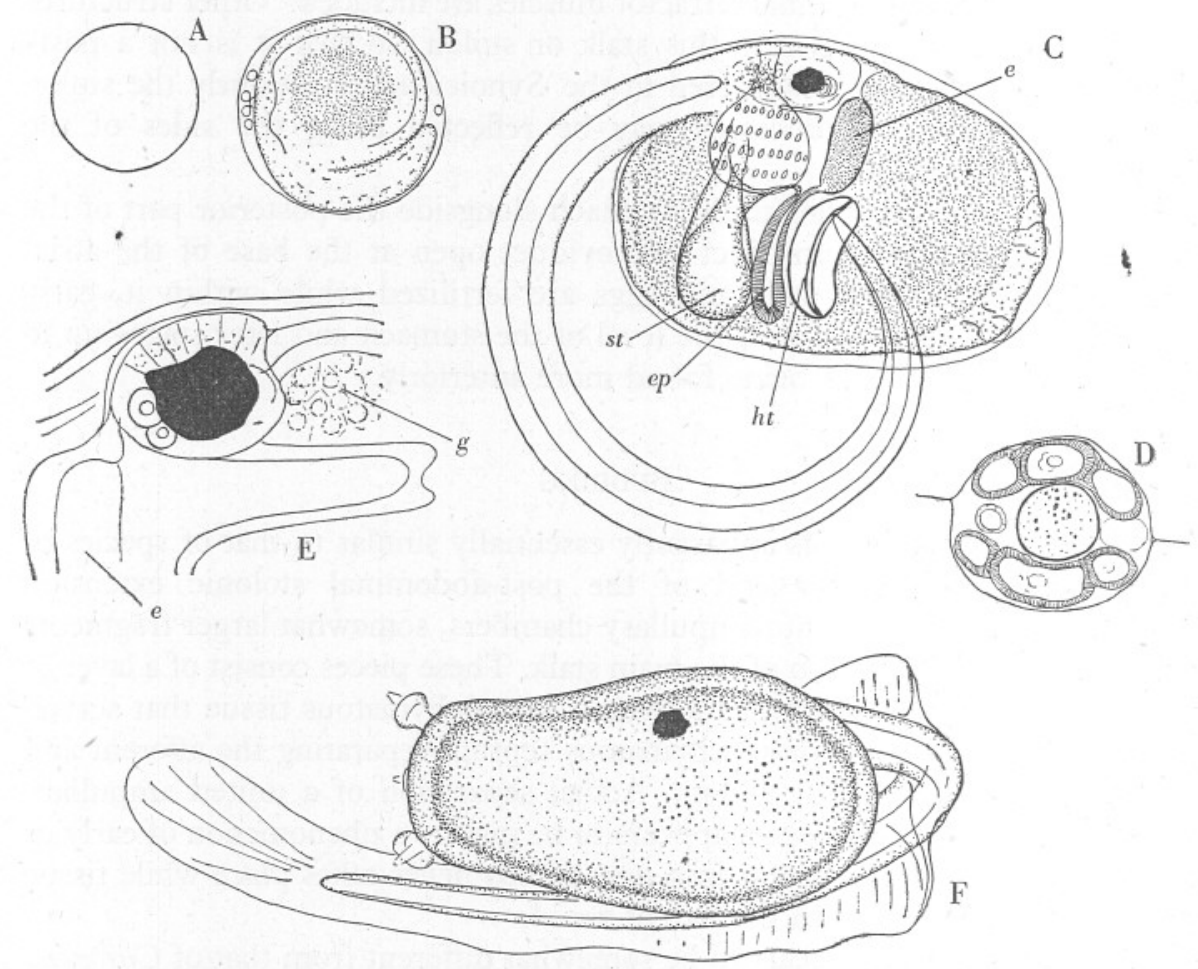

Fig. 2. Pycnoclavella, development of tadpole. A, egg. B, embryo within membrane. C, tadpole near time of liberation, all drawn to same scale. D, cross-section through horizontally twisted tail showing central notochord cell and lateral bands of muscle cells. E, sensory vesicle of tadpole at higher magnification, showing absence of otolith and presence of large mass of ocellus pigment together with two spherical lens cells. F, fully developed tadpole drawn from living specimen. $e$, endostyle; $e p$, epicardium; $g$, ganglion; $h t$, heart; st, stomach.

pattern established by Conklin (1905) for the smaller eggs of Styela, Ciona and Phallusia is not significantly affected. During embryonic development there is considerable growth, the trunk of the tadpole exclusive of the tail having a length several times the diameter of the egg.

At the time of liberation of the tadpole the trunk is greatly distended and the permanent ascidian structure contained within is considerably advanced 
(Fig. 2C). The tail is large and well developed, having a broad cuticular fin throughout its length and extending as a blade beyond, the whole being twisted through $90^{\circ}$, as in all ascidian tadpoles developing from large or yolky eggs excepting those of the Pleurogona (Ptyochobranchia). Muscle tissue lies on each side of the central notochord as a band three cells wide (Fig. 2D). The notochord itself consists of about 40 cells. The free-swimming period of the few living tadpoles studied lasted approximately $\mathrm{I} \mathrm{hr}$., a period consistent with the very local and selective habitat of the species. At $18^{\circ} \mathrm{C}$. the stroke of the tail was 25-30 per sec. and the speed about $3 \mathrm{~mm}$. per sec.

The trunk of the living tadpole (Fig. $2 \mathrm{~F}$ ) is a dense green and the internal organs hard to distinguish. The green colour is due to enormous numbers of peculiar bladder cells congesting all internal space not otherwise occupied. There are three typical adhesive organs at the anterior end, each with a stalk deeply invaginated. Of the larval organs per se the sensory vesicle is unique. While a number of ascidian tadpoles are known with only an otolith but no ocellus, Pycnoclavella alone of those so far examined has an ocellus but no otolith (the Thaliacean condition is not relevant to this discussion). The vesicle (Fig. $2 \mathrm{E}$ ) is not noticeably abnormally small, yet it contains no trace of an otolith while the ocellus itself is a little unusual. The mass of pigment is relatively large although the associated retinal cells do not appear to be correspondingly numerous. The lens cells, however, which are three in the great majority of ascidian tadpoles, are here represented only by two.

As in most yolky ascidian eggs, the development of the larval (tadpole) structure is relatively retarded, probably as in other forms due to the slow differentiation of yolk-laden notochord cells (cf. Berrill, I935 a, b). Accordingly the permanent ascidian structure is relatively well developed within the active tadpole, and lies mainly in the posterior half of the trunk with the axis vertical to the long axis of the tadpole. The mouth is formed though not functionally open, and the pair of peribranchial sacs that appear independently on each side at an earlier stage are fused dorsally to form the atrial aperture. The endostyle is short and thick. Adjacent to it on each side the peribranchial sac is perforated by four rows of definitive stigmata, with nearly the same number per row as in the mature zooid. In the ventral part of the trunk, the pharynx opens into the oesophagus and stomach, the digestive canal as a whole forming a vertical $U$-shaped tube. Immediately in front of the oesophageal opening and behind the base of the endostyle, a second outgrowth extends ventrally from a pair of initial evaginations from the floor of the pharynx to form the epicardium. It later loses its connexion with the pharynx. Anteriorly to the epicardium and ventrally to the endostyle, but not connected with either, lies the large pericardium and heart. 


\section{Postlarval Development}

After settling the tail is rapidly absorbed, complete absorption taking not more than an hour. After about $\mathrm{I} 2 \mathrm{hr}$. (at $\mathrm{I} 8^{\circ} \mathrm{C}$.) the tail consists of a compact, more or less spherical, mass of cells attached to the posterior end of the trunk; the adhesive organs no longer are recognizable, and at the anterior region three large epidermal outgrowths appear (Fig. 3A). The rate of further development is somewhat variable, the permanent organs still being in a non-functioning state 3 days later, but after 5 days varying from an inactive condition to one in
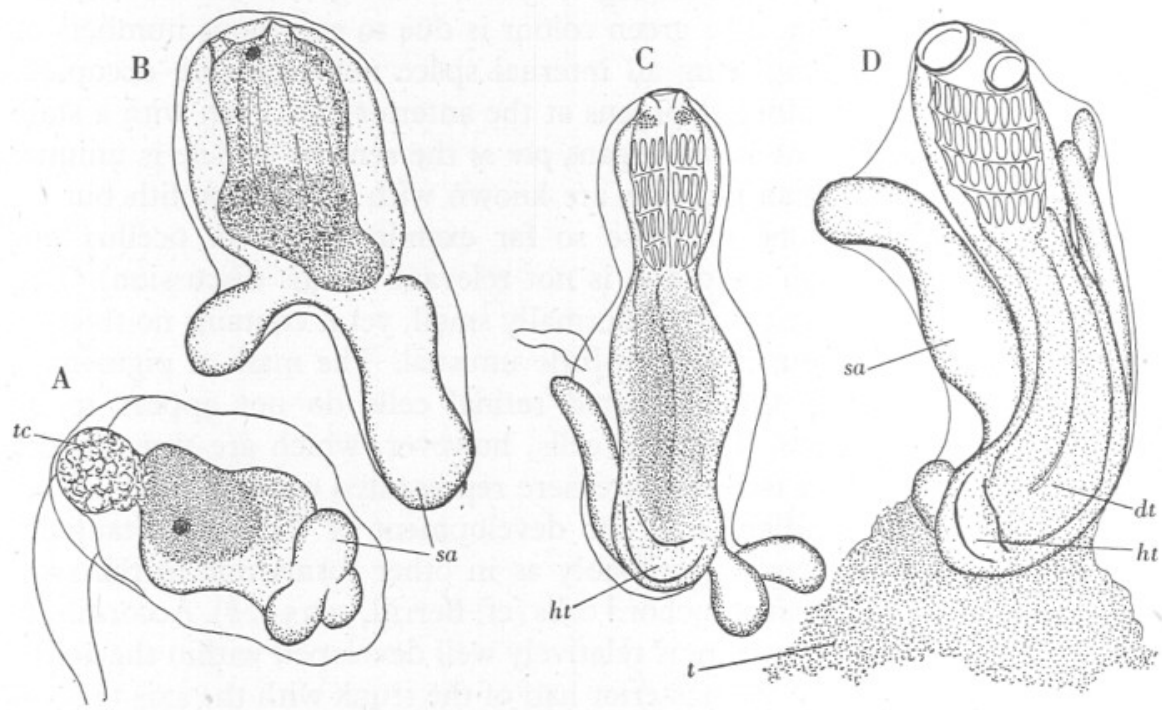

Fig. 3. Pycnoclavella, metamorphosis and post-larval development (at $\mathrm{I} 8^{\circ} \mathrm{C}$.). $\mathrm{A}, \mathrm{I} 2 \mathrm{hr}$. after attachment with tail absorbed and anterior ampullae growing. B, C, 3-5 days later, showing abdominal extension, further growth of ampullae, and formation of active gill slits. D, individual two weeks after attachment with sheet of test substance growing over substratum. $d t$, digestive tube; $h t$, heart; $s a$, stolonic ampulla; $t$, test substance; $t c$, mass of tail cells.

which the heart, siphons and gill-slits are all fully functional (Fig. 3 B, C). At this time the thorax has become transparent and virtually colourless, except for a pair of prominent pigment patches, one on each side of the pharynx in front of the most anterior row of stigmata. The abdomen is greatly elongated, and dense with the green cells noted in the tadpole. The heart now lies at the base of the abdomen. Of the three epidermal outgrowths, one usually continues to grow and the others shrink. At the end of two weeks (Fig. 3D) little further change has occurred, at least under laboratory conditions, the only obvious growth being that of a sheet of tunicin, richly impregnated with small brown cells, over the substratum. 


\section{REFERENCES}

BerRILl, N. J., I935a. Studies in Tunicate Development. Pt. III. Differential retardation and acceleration. Philos. Trans. Roy. Soc., B, Vol. ccxix, pp. 256-326. I935b. Cell division and differentiation in asexual and sexual development. fourn. Morph., Vol. LvII, pp. 353-427.

ConkLIN, E. G., I905. The organization and cell lineage of the ascidian egg. Fourn. Acad. Sci. Philadelphia, Ser. 2, Vol. xIII, pp. I-I I9.

Garstang, W., I89I. Report on the Tunicata of Plymouth. Fourn. Mar. Biol. Assoc., Vol. II, pp. 47-67.

GIARD, A., I873. Contributions à l'histoire naturelle des Synascidies. Arch. Zool. Exper., T. II, pp. 488-5I4.

Huxley, J. S., I926. Studies in dedifferentiation. VI. Reduction phenomena in Clavellina lepadiformis. Pubb. Staz. Zool. Napoli, Vol. vII, pp. I-35..

LAHIlle, F., I890. Recherches sur les Tuniciers des côtes de France. Toulouse. 330 pp.

Scotт, F. M., I945. The developmental history of Amaroecium constellatum. I. Early embryonic development. Biol. Bull., Vol. LxxxviII, pp. I26-38. 